Dept. of Animal and Clinical Nutrition,

Fac. of Vet. Med., Assiut University, Assiut - Egypt

\title{
EVALUATION OF UREA AS A PROTEIN SOURCE IN BROILER DIETS
}

(With 13 Tables)

\author{
By \\ H.A. ABDEL-RAHEEM; A.N. SAYED; NABILA GAZIA \\ and S.M. EL-MASWARY \\ (Received at 13/9/2008) \\ تقيم اليوريا كمصدر للبروتين في علائق بداري التسمين \\ حسن عباس عبدالرحيم ، عبل الباسط نصر سيل ، نبيله جازيه ، \\ صادق المسوري
}

أجريت هذه الدراسة في تجربتين إحداهما تمهيدية والأخرى رئيسية. أجريت التجربة التمهيديـة

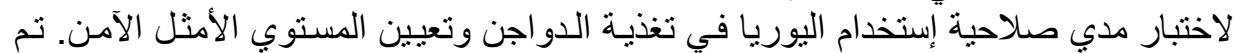

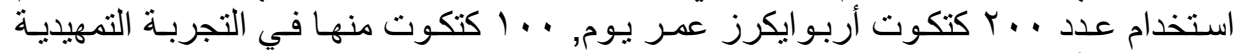

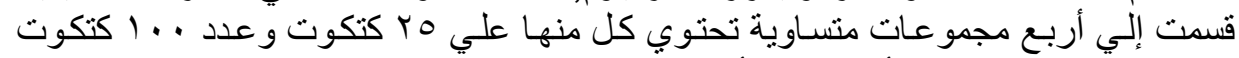

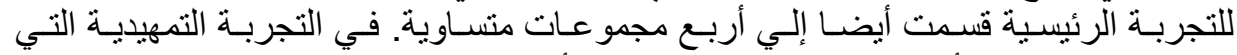

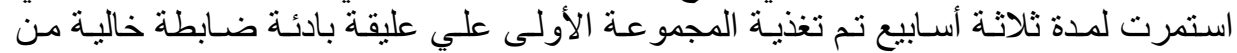

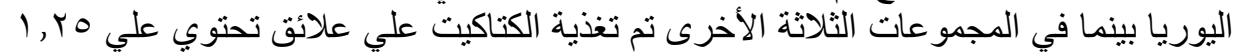

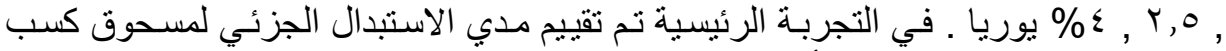

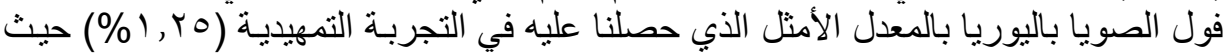

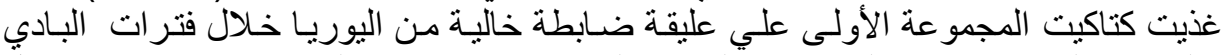

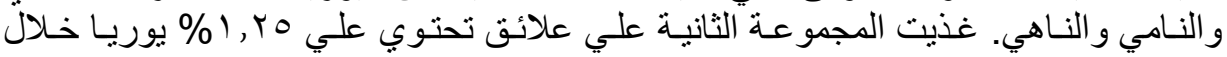

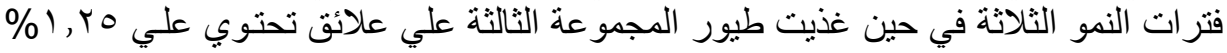

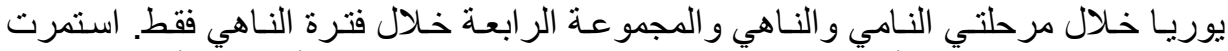

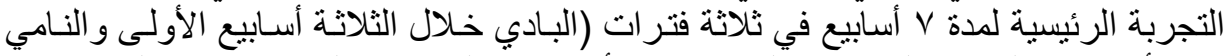

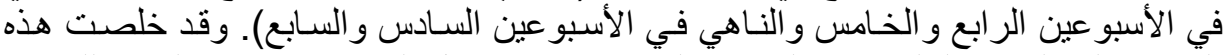

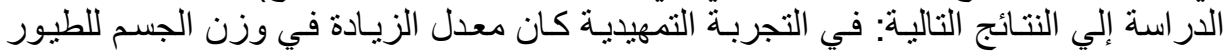

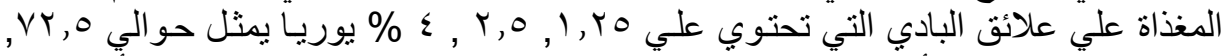
\% rV, r , or, V

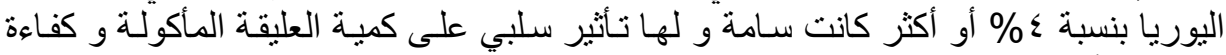

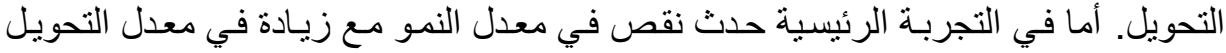

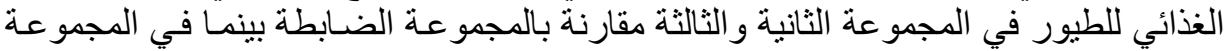

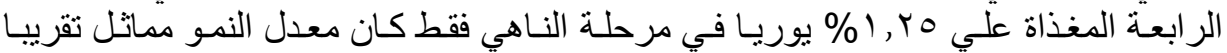

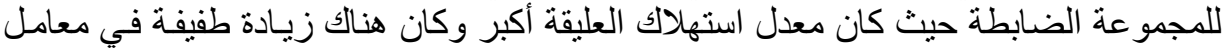




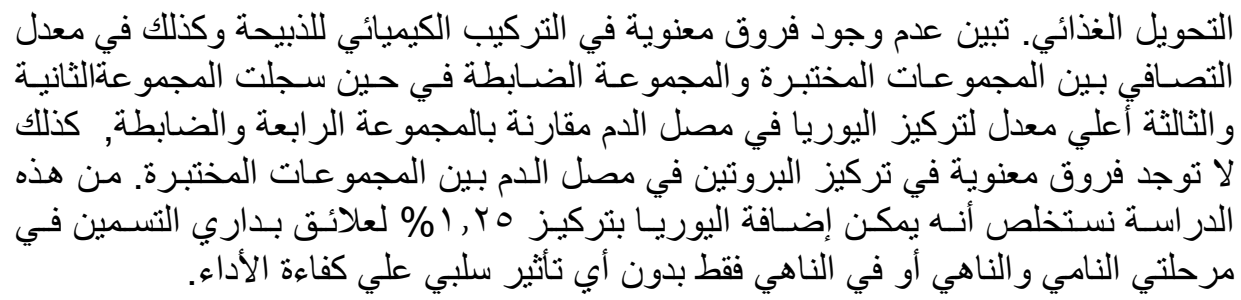

\section{SUMMARY}

This work was conducted in two experiments, the pre-experimental test and the main experiment. The pre-experimental test was tested the validity of urea for poultry feeding and the mostly safe dietary level was determined. A total number of 200 one-day old chicks (Arbor Acres), 100 for a pre-experimental test of initial weight $46 \mathrm{~g}$ distributed into four equal groups (25 chicks/group) and 100 for the main experiment, weighing on the average $55 \mathrm{~g}$ were allocated at random into four groups each of 25 chicks. The pre-experimental test extended for only 3 weeks (starting period). The first group was fed on a control starter free from urea, while in the other three groups, the urea form 1.25, $2.5 \& 4 \%$ of the diet, respectively. In the main experiment, urea was tested as soybean meal substituted at $1.25 \%$ as the pre-experimentation dictated. The first group was fed on a control diet free from urea during the three feeding phases; starting, growing and finishing. The second group was fed on the diet containing $1.25 \%$ urea along the three feeding phases, while the third \& fourth groups for the last $2^{\text {nd }} \& 3^{\text {rd }}$ phases or last third phase respectively. The main experiment extended for 7 weeks duration in three feeding phases; starting through the first 3 weeks, growing from 3 - 5 weeks \& finishing from 5 - 7 weeks of age. In the preexperimental urea test, the $1.25 \%$ urea group gained a body weight of $72.5 \%$ that of the control, while the $2.5 \& 4 \%$ urea groups gained 53.7 $\& 37.2 \%$ respectively. In addition, urea may be toxic at a level of $4 \%$ or more and had adverse effect on feed intake and conversion. In the main experiment, the second group had a reduction in growth rate by $25 \%$ and consuming less amount of food as that of control (84.3\%), and slight high feed conversion (2.52) compared with control (2.21). In the third group, more feed consumed and less weight gain and by turn more feed conversion. In the fourth group in which urea feeding was limited to the finishing period, growth rate was nearly similar to control and more feed consumed resulting in a feed conversion index slightly higher than the control. There were no differences in the chemical composition of carcass meat and carcass dressing values between different experimental 
groups. In contrast, serum urea value of the $2^{\text {nd }} \& 3^{\text {rd }}$ groups fed urea supplemented diets recorded the highest values compared to $4^{\text {th }}$ and control one, while no differences in the total serum protein were found between the different experimental groups. It could be concluded that, urea can be added to the diets of broiler chicks at a level of $1.25 \%$ during growing-finishing \& finishing periods without adversely effect on the performance.

Key words: urea, protein, performance, broilers.

\section{INTRODUCTION}

Hunger and malnutrition of the ever-increasing human population of developing countries can be alleviated to some extent through the growth of broiler segment of the poultry industry. However, in developing countries, both protein and energy-rich conventional dietary ingredients such as soybean and maize are in short supply, posing a constant threat to an orderly development of the broiler industry. There is, therefore, a need for greater emphasis to be placed on those feedstuffs which are not in competition with human sector; in particular on unexplored and unconventional based industrial byproducts (Nagalakshmi et al., 1999). In non-ruminants, some researchers have suggested that urea is unable to be utilized and that it has no nutritional value for poultry (Kobayashi et al. 1981). Others suggested that urea may replace some-non essential amino acids in diet of nonruminants (Sucio et al., 1990). However, significant increase in mass gain has been observed when low levels of urea were used in broiler chicks (Pervaz et al., 1996). It has been reported that gut microorganisms are responsible for the growth-promoting effect of urea in chicks. Higher levels of urea are also reported to be toxic to chickens (Guo, 1983; Chandra et al., 1984; Jabbar, 1994; Pervaz et al., 1996 \& Hussain, 1995). Inclusion of urea may, however, be of some value during the first stage of rearing of replacement pullets, since growth responses to non-protein nitrogen sources had been obtained with birds up to 4 weeks of age (Davis \& Martindale, 1973). Dietary urea could be utilized for growth of chicks when crystalline amino acid diets low in non-essential nitrogen or diets containing low concentrations of intact protein were fed (Blair \& Lee, 1973; Davis \& Martindale, 1973) and that portal ammonia was retained to a greater degree in chickens fed on a low protein diets than in those fed on a high protein one (Karasawa, 1986). An experiment has therefore been performed to study the effect of urea 
which is the cheapest \& most readily available source of non-protein nitrogen as soybean meal substitution on the growth performance and subsequent carcass traits of broilers.

\section{MATERIALS and METHODS}

\section{I- Experimental chicks:}

A total number of 200 one-day old chicks (Arbor Acres), 100 for a pre-experimental urea test of initial weight $46 \mathrm{~g}$ distributed into four equal groups (25 chicks/group) and 100 for the main experiment, weighing on the average $55 \mathrm{~g}$ were allocated at random into four groups each of 25 chicks. The chicks were floor reared in an experimental room bedded by a layer of chaffed wheat straw and provided by clean feeders and waterers. All birds were kept under standard hygienic conditions and were subjected to a prophylactic vaccination and pharmacological program against viral and bacterial diseases specially New Castle Virus disease (NDV).

\section{II- Experimental design:}

As urea is one of the common non-protein nitrogenous sources but for animal, a pre-experimental test was performed. In the preexperimental test, the validity of urea for poultry was tested and the mostly safe dietary level was determined. The main experiment was designed to trace the value of urea as protein source and substitute soybean meal. Three groups other than control were allotted. The second for feeding the substitute along the three feeding phases (Starting, growing \& finishing), while the third \& fourth groups for the last $2^{\text {nd }} \&$ $3^{\text {rd }}$ phases or last third phase respectively. The following table show the design which put an age consideration in feeding.

\begin{tabular}{|l|c|c|c|c|}
\hline \multirow{2}{*}{ Phase } & \multicolumn{4}{|c|}{ Groups } \\
\cline { 2 - 5 } & 1 & 2 & 3 & 4 \\
& Control & $1.25 \%$ urea & $1.25 \%$ urea & $1.25 \%$ urea \\
\hline Starting & - & + & - & - \\
Growing & - & + & + & - \\
Finishing & - & + & + & + \\
\hline
\end{tabular}

\section{III- Diets \& feeding:}

The used feeding-stuffs were analyzed for nutrients content following AOAC (1984) official method (Table, 1) and all diets were formulated to contain the $\mathrm{ME}$ density and $\mathrm{CP}$ concentration recommended by NRC (1994). 
In the pre-experimental test, four groups were fed. The first was considered as the control to which the other groups were compared. The other three groups were fed on mixed diets containing 1.25, 2.5 and $4 \%$ urea respectively as shown in Table (2).

In the main experiment, a control group was fed on three diets, the starter, grower \& finisher based on soybean meal as the main protein source and free from urea. In the other three groups, the second group was fed three phases diets containing $1.25 \%$ urea, while in the third group, only the starter was based on the soybean meal, and in the fourth group the starter and grower were both based on the soybean meal. In the grower \& finisher of the third group and finisher of the fourth, the soybean meal substitute $1.25 \%$ was fed (Table, 3 ).

The pre-experiment extended for only 3 weeks, the starting period, while the main experiment for 7 weeks duration in three feeding phases (starter, grower and finisher). Performance during each period for different groups was recorded. Chicks were fed ad-libitum with free access to diets and fresh water through the experimental period. Birds were checked twice daily and the weight of dead birds was used to adjust the average feed consumption and body weights.

\section{IV- Tested parameters:}

\section{A- Growth performance and feed conversion:}

The amount of feed consumed was weekly recorded in each of the different groups. The average amount consumed by each bird was calculated by dividing the weekly consumed food by its respective number of birds in each group at this week.

Regarding the development of the body weight and weight gain, the birds were individually weighed every week and the live weight changes were taken as the criteria of the effect of the different treatments, and as a measure for growth.

$$
\text { Relative growth rate }=\frac{\left(W_{1}-W_{2}\right)}{1 / 2\left(W_{1}+W_{2}\right)}
$$

The standard deviations and errors were calculated. The absolute weight of the bird gives an idea about the body weight development during the experimental period, the growth was measured and expressed in percentage relative to the body weight in order to compare the different groups in relation to its relative rate of growth. The amount of feed consumed was divided by the body weight gain of the bird in order to calculate the rate of feed conversion. Experimental crude data were subjected to several statistical analysis, from which the means, standard 
errors were calculated and differences were tested for significances using (t) test (SAS, 1996).

\section{B- Blood samples, carcass traits, and biochemistry:}

Five randomly selected birds from each group were slaughtered at the end of the main experiment for carcass traits, chemical composition analysis, and blood samples collections. Feed but not water was removed from birds 12 hours prior to slaughtering. A blood specimen was collected from each of the slaughtered birds of all the groups at the end of the experiment. The blood samples were allotted to clot at ambient temperature, centrifuged for 10 minuets at $3000 \mathrm{rpm}$, and serum from each sample was extracted. The serum samples $(1 \mathrm{ml} / \mathrm{vial})$ were kept at $-20^{\circ} \mathrm{C}$ until biochemical parameters were measured. Dressed carcass as the weight of the slaughtered birds after removal of feathers, head and feet but including all the offals, (edible or not) were recorded. The weights of some internal organs of birds including gizzard, pro-ventriculus, liver, spleen and heart were recorded at the end of the experiment and calculated as a percentage of dressed carcass weight. The biochemical parameters, including total serum protein and its fractions (albumin and globulin) and urea were determined using standard test kits supplied by Biomerieux (Baines / France).

\section{C- Monetary value:}

Total production cost was calculated including prices of one day old chicks, feeding, heating, veterinary care, management and housing. Selling price was calculated by multiplying total live body weight of the birds produced by the price per unit weight commonly offered in the market.

Net revenue $=$ Price of body weight - Total production costs

Net revenue

Economic feed efficiency $($ EFE $)=----\cdot------\times 100$

Total production cost

Relative economic feed efficiency $($ REFE $)=\frac{\text { EFEOf group }}{\text { EFEof control }} \times 1$ OO 


\section{RESULTS}

Table 1: Chemical composition (\%) and metabolizable energy value of the ingredients.

\begin{tabular}{|l|c|c|c|c|c|c|c|}
\hline Ingredients & DM* & CP & EE & CF & Ash & NFE & $\begin{array}{c}\text { ME } \\
\text { Mcal/kg }\end{array}$ \\
\hline Yellow corn & 88.7 & 8.6 & 3.2 & 3.0 & 1.3 & 72.6 & 3.35 \\
Fish meal & 92.2 & 70.4 & 8.7 & 0.76 & 10.3 & 2.04 & 3.19 \\
Soybean meal & 88.3 & 44.0 & 0.9 & 8.0 & 5.2 & 30.2 & 2.23 \\
Urea & 99.0 & $290.6^{* *}$ & - & - & - & - & - \\
Dried fat & 99.0 & - & 99.0 & - & - & - & 7.20 \\
\hline
\end{tabular}

*DM=Dry matter, $\mathrm{CP}=$ Crude protein, $\mathrm{EE}=$ Ether extract, $\mathrm{CF}=$ Crude fibre,

$\mathrm{NFE}=$ Nitrogen free-extract, $\mathrm{ME}=$ Metabolizable energy. $* *$ Protein equivalent

Table 2: Physical \& chemical composition of the diets fed during the pre-experimental test.

\begin{tabular}{|l|c|c|c|c|}
\hline \multirow{2}{*}{ Ingredients } & \multicolumn{3}{|c|}{ Urea } \\
\cline { 2 - 5 } & Control & $1.25 \%$ & $2.5 \%$ & $4 \%$ \\
\cline { 3 - 5 } & & & & \\
Physical composition: & & 56.89 & 68.47 & 81.79 \\
Yellow corn & 45.50 & 26.52 & 16.00 & 3.47 \\
Soybean meal & 36.94 & 4.00 & 4.00 & 4.00 \\
Fish meal & 4.00 & 7.51 & 5.01 & 2.01 \\
Dried fat & 10.06 & 1.25 & 2.50 & 4.00 \\
Urea & --- & 1.36 & 1.45 & 1.60 \\
Di-calcium phosphate & 1.29 & 1.39 & 1.40 & 1.40 \\
Limestone, ground & 1.44 & 0.37 & 0.37 & 0.37 \\
Common salt & 0.37 & 0.26 & 0.31 & 0.81 \\
Lysine & --- & 0.15 & 0.19 & 0.25 \\
Methionine & 0.10 & 0.30 & 0.30 & 0.30 \\
Premix* & 0.30 & & & \\
\hline Chemical composition: & & 23.01 & 23.02 & 23.01 \\
Crude protein & 22.98 & 3200 & 3208 & 3200 \\
ME (Kcal/kg diet) & 3200 & 0.50 & 0.50 & 0.50 \\
Methionine & 0.50 & 1.33 & 1.33 & 1.33 \\
Lysine & 1.33 & 1.01 & 1.00 & 1.00 \\
Calcium & 1.03 & 0.66 & 0.63 & 0.61 \\
Total phosphorus & 0.66 & 0.45 & 0.45 & 0.45 \\
Available phosphorus & 0.45 & & & \\
\hline
\end{tabular}

* Vigora premix (vitamins \& minerals) 
Table 3: Physical \& Chemical composition of diets fed during the main experiment

\begin{tabular}{|c|c|c|c|c|c|c|}
\hline \multirow{3}{*}{ Ingredients } & \multicolumn{6}{|c|}{ Diets } \\
\hline & \multicolumn{3}{|c|}{ Control } & \multicolumn{3}{|c|}{$1.25 \%$ urea } \\
\hline & Starter & Grower & Finisher & Starter & Grower & Finisher \\
\hline Physical composition: & & & & & & \\
\hline Yellow corn & 45.5 & 58.79 & 67.51 & 56.89 & 70.44 & 79.32 \\
\hline Soybean meal & 36.94 & 27.57 & 21.32 & 26.52 & 17.03 & 10.77 \\
\hline Fish meal & 4.00 & 4.00 & 4.00 & 4.00 & 4.00 & 4.00 \\
\hline Dried fat & 10.06 & 6.78 & 4.66 & 7.51 & 4.15 & 1.95 \\
\hline Urea & --- & --- & --- & 1.25 & 1.25 & 1.25 \\
\hline Di-calcium phosphate & 1.29 & 0.90 & 0.60 & 1.36 & 0.91 & 0.68 \\
\hline Limestone, ground & 1.44 & 1.37 & 1.40 & 1.39 & 1.44 & 1.35 \\
\hline Common salt & 0.37 & 0.27 & 0.21 & 0.37 & 0.27 & 0.21 \\
\hline Lysine & --- & --- & --- & 0.26 & 0.15 & 0.14 \\
\hline Methionine & 0.10 & 0.02 & --- & 0.15 & 0.06 & 0.03 \\
\hline Premix & 0.30 & 0.30 & 0.30 & 0.30 & 0.30 & 0.30 \\
\hline Chemical composition: & & & & & & \\
\hline Crude protein & 22.98 & 20.00 & 18.00 & 23.01 & 20.00 & 18.01 \\
\hline $\mathrm{ME}$ (Kcal/kg diet) & 3200 & 3200 & 3200 & 3200 & 3200 & 3200 \\
\hline Calorie/protein ratio & 139.2 & 160.0 & 177.8 & 139.0 & 160.0 & 177.7 \\
\hline Methionine & 0.50 & 0.38 & 0.34 & 0.51 & 0.38 & 0.32 \\
\hline Lysine & 1.33 & 1.10 & 0.96 & 1.33 & 1.01 & 0.86 \\
\hline Calcium (\%) & 1.03 & 0.90 & 0.82 & 1.0 & 0.90 & 0.80 \\
\hline Total phosphorus (\%) & 0.66 & 0.57 & 0.50 & 0.66 & 0.54 & 0.48 \\
\hline Available P (\%) & 0.45 & 0.36 & 0.30 & 0.45 & 0.35 & 0.30 \\
\hline
\end{tabular}

Table 4: Mortality rate of broilers in the pre-experimental test

\begin{tabular}{|c|c|c|c|c|}
\hline \multirow{2}{*}{ Age in weeks } & \multicolumn{4}{|c|}{ Groups } \\
\cline { 2 - 5 } & Control & \multicolumn{3}{|c|}{ Urea } \\
\cline { 2 - 5 } & 1 & $2(1.25 \%)$ & $3(2.5 \%)$ & $4(4 \%)$ \\
\hline 1 & 1 & 1 & - & 1 \\
2 & - & - & 1 & 2 \\
3 & - & & 1 & 2 \\
\hline
\end{tabular}

Table 5: Body weight development (g) of broilers in the preexperimental test.

\begin{tabular}{|c|c|c|c|c|}
\hline \multirow{2}{*}{ Age in weeks } & \multicolumn{4}{|c|}{ Groups } \\
\cline { 2 - 5 } & Control & \multicolumn{3}{|c|}{ Urea } \\
\cline { 2 - 5 } & 1 & $2(1.25 \%)$ & $3(2.5 \%)$ & $4(4 \%)$ \\
\hline Initial & 46.5 & 46.0 & 47.0 & 45.5 \\
1 & 174.4 & 155.3 & 137.1 & 115.3 \\
2 & 397.2 & 292.6 & 235.4 & 187.2 \\
3 & 713.3 & 516.8 & 382.9 & 265.1 \\
\hline
\end{tabular}


Table 6: Weekly relative growth rate (\%) of broilers in the preexperimental test.

\begin{tabular}{|c|c|c|c|c|}
\hline \multirow{2}{*}{ Age in weeks } & \multicolumn{4}{|c|}{ Groups } \\
\cline { 2 - 5 } & Control & \multicolumn{3}{|c|}{ Urea } \\
\cline { 3 - 5 } & $(1)$ & $2(1.25 \%)$ & $3(2.5 \%)$ & $4(4 \%)$ \\
\hline 1 & 113.09 & 108.60 & 97.88 & 86.83 \\
2 & 77.94 & 70.22 & 52.75 & 47.49 \\
3 & 56.92 & 55.41 & 47.71 & 34.44 \\
\hline
\end{tabular}

Table 7: Body weight development $(\mathrm{g})$ of broilers in the main experimental test.

\begin{tabular}{|c|c|c|c|c|}
\hline \multirow{2}{*}{$\begin{array}{c}\text { Age in } \\
\text { weeks }\end{array}$} & Control & \multicolumn{3}{|c|}{ Groups } \\
\cline { 2 - 5 } & $(1)$ & $(2)$ & $(3)$ & $(4)$ \\
\cline { 3 - 5 } & $56.2 \pm 0.6$ & $55.3 \pm 0.7^{-4}$ & $55.3 \pm 0.7$ & $55.1 \pm 0.6$ \\
1 & $185.3 \pm 4.03^{\mathrm{b} *}$ & $161.1 \pm 4.8^{\mathrm{c}}$ & $201.8 \pm 4.6^{\mathrm{a}}$ & $195.9 \pm 6.1^{\mathrm{ab}}$ \\
2 & $390.6 \pm 10.4^{\mathrm{a}}$ & $306.5 \pm 9.5^{\mathrm{b}}$ & $388.2 \pm 8.4^{\mathrm{a}}$ & $381.8 \pm 12.5^{\mathrm{a}}$ \\
3 & $766.5 \pm 14.1^{\mathrm{a}}$ & $523.5 \pm 17.0^{\mathrm{b}}$ & $742.4 \pm 17.5^{\mathrm{a}}$ & $747.7 \pm 23.9^{\mathrm{a}}$ \\
4 & $1024.1 \pm 20.9^{\mathrm{a}}$ & $773.5 \pm 24.1^{\mathrm{c}}$ & $1136.5 \pm 26.7^{\mathrm{b}}$ & $1249.4 \pm 34.8^{\mathrm{a}}$ \\
5 & $1604.7 \pm 26.2^{\mathrm{a}}$ & $1069.4 \pm 38.6^{\mathrm{c}}$ & $1454.7 \mathrm{v} 34.1^{\mathrm{b}}$ & $1584.7 \pm 43.6^{\mathrm{a}}$ \\
6 & $2044.1 \pm 37.5^{\mathrm{a}}$ & $1445.9 \pm 51.1^{\mathrm{c}}$ & $1862.9 \pm 46.7^{\mathrm{b}}$ & $1994.1 \pm 50.7^{\mathrm{a}}$ \\
7 & $2390.3 \pm 46.7^{\mathrm{a}}$ & $1780.6 \pm 60.6^{\mathrm{b}}$ & $2253.5 \pm 56.6^{\mathrm{a}}$ & $2375.9 \pm 58.1^{\mathrm{a}}$ \\
\hline
\end{tabular}

*Figures in the same row having the same superscripts are not significantly different $(\mathrm{P}<0.05)$.

Table 8: Feed intake (g/chick) of the different experimental groups compared with control

\begin{tabular}{|c|c|c|c|c|}
\hline \multirow{3}{*}{$\begin{array}{l}\text { Period in } \\
\text { weeks }\end{array}$} & \multicolumn{4}{|c|}{ Groups } \\
\hline & \multirow{2}{*}{$\begin{array}{c}\text { Control } \\
\text { (1) }\end{array}$} & \multicolumn{3}{|c|}{ Urea $(1.25 \%)$} \\
\hline & & (2) & (3) & (4) \\
\hline $0-1$ & 173 & 156.0 & 186.0 & 178.5 \\
\hline $1-2$ & 414.5 & 406.0 & 420.0 & 431.5 \\
\hline $2-3$ & 675.3 & 603.0 & 646.5 & 648.5 \\
\hline $3-4$ & 873.2 & 652.5 & 887.5 & 868.0 \\
\hline $4-5$ & 909.5 & 744.0 & 885.0 & 902.0 \\
\hline $5-6$ & 1055.3 & 891.0 & 1092.5 & 1190.0 \\
\hline $6-7$ & 1068.4 & 902.5 & 1158.5 & 1188.0 \\
\hline
\end{tabular}


Table 9: Stage performance of chicks in the different experimental groups of the main experimental test.

\begin{tabular}{|c|c|c|c|c|}
\hline \multirow{3}{*}{ Age in weeks } & \multicolumn{4}{|c|}{ Groups } \\
\hline & \multirow{2}{*}{$\begin{array}{c}\text { Control } \\
\text { (1) }\end{array}$} & \multicolumn{3}{|c|}{ Urea $(1.25 \%)$} \\
\hline & & (2) & (3) & (4) \\
\hline \multicolumn{5}{|l|}{ Feed intake } \\
\hline $0-3$ & 1262.7 & 1165.0 & 1252.5 & 1258.5 \\
\hline $3-5$ & 1782.6 & 1396.5 & 1772.5 & 1770.0 \\
\hline $5-7$ & 2123.7 & 1793.5 & 2251.0 & 2379.0 \\
\hline $0-7$ & 5169.0 & 4355.0 & 5276.0 & 5407.5 \\
\hline \multicolumn{5}{|l|}{ Weight gain } \\
\hline $0-3$ & $710.2 \pm 13.8^{\text {a }}$ & $468.3 \pm 16.6^{b}$ & $687.1 \pm 17.3^{\mathrm{a}}$ & $692.5 \pm 23.4^{\mathrm{a}}$ \\
\hline $3-5$ & $838.2 \pm 22.8^{\mathrm{a}}$ & $545.9 \pm 24.1^{\mathrm{c}}$ & $712.4 \pm 18.9^{b}$ & $837.1 \pm 28.4^{\mathrm{a}}$ \\
\hline $5-7$ & $785.9 \pm 36.5^{\mathrm{a}}$ & $711.2 \pm 32.5^{b}$ & $798.8 \pm 36.5^{\text {a }}$ & $791.2 \pm 34.3^{\mathrm{a}}$ \\
\hline $0-7$ & $2334.4 \pm 46.8^{\mathrm{a}}$ & $1725.3 \pm 60.2^{b}$ & $2198.2 \pm 56.5^{\mathrm{a}}$ & $2320.8 \pm 58.7^{\mathrm{a}}$ \\
\hline \multicolumn{5}{|c|}{ Feed Conversion indices } \\
\hline $0-3$ & 1.77 & 2.48 & 1.82 & 1.78 \\
\hline $3-5$ & 2.12 & 2.55 & 2.48 & 2.11 \\
\hline $5-7$ & 2.70 & 2.52 & 2.81 & 3.00 \\
\hline $0-7$ & 2.21 & 2.52 & 2.40 & 2.33 \\
\hline
\end{tabular}

* Figures in the same row having the same superscripts are not significantly different $(\mathrm{P}<0.05)$.

Table 10: Dressed carcass as \% of body weight and some internal organs (as \% of dressed carcass) of broilers in the main experiment.

\begin{tabular}{|c|c|c|c|c|}
\hline \multirow{2}{*}{ Item } & \multicolumn{4}{|c|}{ Groups } \\
\cline { 2 - 5 } & Control & \multicolumn{3}{|c|}{ Urea (1.25\%) } \\
\cline { 2 - 5 } & 1 & 2 & 3 & 4 \\
\hline Body weight (g) & $2390.6 \pm 46.7^{\mathrm{a}^{*}}$ & $1780.6 \pm 60.6^{\mathrm{b}}$ & $2253.0 \pm 56.6^{\mathrm{a}}$ & $2375.9 \pm 58.1^{\mathrm{a}}$ \\
Dressed carcass (g) & $1731.7 \pm 36.7^{\mathrm{a}}$ & $1260.1 \pm 48.9^{\mathrm{b}}$ & $1604.5 \pm 44.1^{\mathrm{a}}$ & $1755.1 \pm 64.0^{\mathrm{a}}$ \\
& & & & 71.2 \\
Dressed carcass as & 72.44 & 70.77 & & 73.87 \\
\% of body weight & & & & \\
Gizzard & $3.23 \pm 0.24^{\mathrm{b}}$ & $3.96 \pm 0.18^{\mathrm{a}}$ & $3.62 \pm 0.37^{\mathrm{b}}$ & $3.65 \pm 0.46^{\mathrm{b}}$ \\
Pro-ventriculus & $0.73 \pm 0.07^{\mathrm{b}}$ & $0.84 \pm 0.06^{\mathrm{a}}$ & $0.60 \pm 0.05^{\mathrm{b}}$ & $0.73 \pm 0.06^{\mathrm{b}}$ \\
Liver & $3.77 \pm 0.62^{\mathrm{b}}$ & $4.70 \pm 0.53 \pm^{\mathrm{a}}$ & $3.55 \pm 0.42 \pm \mathrm{b}^{\mathrm{b}}$ & $4.15 .36 \pm^{\mathrm{a}}$ \\
Spleen & $0.28 \pm 0.02$ & $0.25 \pm 0.03$ & $0.21 \pm 0.02$ & $0.27 \pm 0.03$ \\
Heart & $0.71 \pm 0.11$ & $0.81 \pm 0.08$ & $0.80 \pm 0.09$ & $0.73 \pm 0.13$ \\
\hline
\end{tabular}

* Figures in the same row having the same superscripts are not significantly different $\quad(\mathrm{P}<0.05)$ 
Table 11: Chemical composition (\%) of broiler meat of broilers in the main experimental test.

\begin{tabular}{|c|c|c|c|c|}
\hline \multirow{2}{*}{ Groups } & \multirow{2}{*}{ DM } & \multicolumn{3}{|c|}{ On DM basis } \\
\cline { 3 - 5 } & & CP & EE & Ash \\
\hline Control (1) & 25.64 & 83.82 & 12.50 & 3.65 \\
2 & 24.85 & 82.82 & 13.20 & 3.93 \\
3 & 25.35 & 83.37 & 12.61 & 3.98 \\
4 & 26.19 & 83.60 & 12.63 & 3.73 \\
\hline
\end{tabular}

Table 12: Serum protein parameters and serum urea of broilers in the main experimental test.

\begin{tabular}{|l|c|c|c|c|}
\hline Parameters & Control & \multicolumn{3}{|c|}{ Urea groups } \\
\cline { 3 - 5 } & 1 & 2 & 3 & 4 \\
\hline Total protein (g/dl) & 4.19 & 3.78 & 3.69 & 4.37 \\
Albumin (g/dl) & 3.39 & 3.13 & 3.08 & 3.43 \\
Globulins (g/dl) & 0.80 & 0.65 & 0.61 & 0.94 \\
Urea (mg/dl) & 1.18 & 7.63 & 8.19 & 2.60 \\
\hline
\end{tabular}

Table 13: Economical evaluation of broilers in the main experimental test.

\begin{tabular}{|l|c|c|c|c|}
\hline \multirow{2}{*}{ Item } & Control & \multicolumn{3}{|c|}{ Urea groups } \\
\cline { 3 - 5 } & 1 & 2 & 3 & 4 \\
\hline Total feed cost (LE) & 11.35 & 8.74 & 10.75 & 11.33 \\
Total production cost (LE) & 13.85 & 11.24 & 13.25 & 13.83 \\
Body weight (g/chick) & 2390.3 & 1780.6 & 2253.5 & 2375.9 \\
Price of body weight (LE) & 19.12 & 14.24 & 18.03 & 19.01 \\
Net revenue (LE) & 5.27 & 3.00 & 4.78 & 5.18 \\
Economical feed efficiency (\%) & 38.05 & 26.69 & 36.08 & 37.45 \\
Relative economic feed efficiency & 100 & 70.14 & 94.82 & 98.42 \\
\hline
\end{tabular}

\section{DISCUSSION}

\section{I-The Pre-experimental test:}

The mortality rate was nearly normal as only one chicks died from the 25 chicks of the control and $1.25 \%$ urea group and 2 chicks from the $2.5 \%$ urea group. From the $4 \%$ urea group, 5 chicks died mating a rate of $25 \%$ in the 3 weeks of feeding pointing a toxic effect of urea at high level as shown in Table (4).

The decreasing effect of urea on body weight was clear from the first week of feeding and is related to the level of urea added. The $1.25 \%$ 
urea group gained a body weight of $72.5 \%$ that of the control, while the $2.5 \% \& 4 \%$ urea groups gained $53.7 \& 37.2 \%$, respectively as shown in Table (5). The relative growth rate in the $1.25 \%$ urea group was slightly affected in the first \& second week and nearly passed unaffected in the third week pointing to a matter of adaptation (Table, 6). In the $2.5 \%$ group, the effect was more clear, while it was more drastic in the $4 \%$ group. The reduced growth rates were not so relevant to the reduced feed intake. It seems that the reduced growth is a matter not only of decreased feed intake but also of decreased efficiency of utilization. It seems that, urea may be toxic at the level of the $4 \%$ or more and have adverse effect on feed intake and conversion resulting in reduced growth rates, but it appear that feeding the level $1.25 \%$ is feasible especially if there is soybean meal shortage or high pricing. The $1.25 \%$ urea allowed about $28 \%$ of the soybean meal to be dispensed with. The results are in agreement with that found by Panda et al. (1995) who reported that the growth and feed efficiency depression were directly proportional to the level of urea in the diet. In addition, the main body weight of chicks was decreased with the increased amount of urea in the diet (Das et al., 1997a). Das et al. (1997b) found that diets containing more than or equal $2 \%$ urea significantly reduced growth. So, the level $1.25 \%$ urea will be tried in main experiment on a phase-basis, as it may be the age which is the factor enabling the chicks to cope with urea toxicity or adverse effects especially the relative growth rate in the $3^{\text {rd }}$ week was nearly equal to that of the control (56.92\% for the control and $5541 \%$ for $1.25 \%$ urea group).

\section{II-The main experiment:}

This experiment was designed after the pre-experimentation test in which the $1.25 \%$ urea level was nominated to be tried on a phasebasis. The level of urea substitution reduced the soybean meal needed to $71.8 \%$ as much as the control level in the starter, $61.8 \%$ in the grower and $50.5 \%$ in the finisher to achieve the optimal protein levels. The reduction in soybean meal was not on a nitrogen equivalency but the soybean meal energy was replaced by corn energy of which the protein content was considered.

\section{A- Body weight development:}

From Table (7), the effect of feeding urea on body weight was noted in the second group from the first week. The reducing effect continued at nearly the same rate for the second week and become most clear in the third. In the fourth week, the growth rate increased to reach $75.53 \%$ of the control in spite of feeding the $1.25 \%$ urea. It could not be 
interpreted as a compensating growth and adaptation condition as the growth returned to be reduced again on the fifth week. In the third group, the growth shot up in the first week of feeding $(110.97 \%$ of control), then continued at an average rate of $92.02 \%$ of the control in the last three weeks. It means that a slight reduction was affected on growth. In the fourth group, the urea was fed in the finishing period and an average rate of growth of $98.48 \%$ that of control and recording no significant effect of urea. The relative growth rate in the second group starting on urea from the first day of age was slightly reduced in the first three weeks and then started to be increased and continued higher than control in the last three weeks. In the third group, slight reducing effect on the fourth \& fifth weeks, no effect on the sixth and slight increasing on the seventh week. In the fourth group, the differences in the finishing phase were not significant. Previous studies on feeding urea through commercial feeds at a level of $1 \%$ urea revealed an increase in both body weight \& carcass mass in broilers (Javed et al., 1995; Pervaz et al., 1996). On the contrary, Panda et al. (1995) and Sharkawy \& Mubark (2003) found a decrease in body weight gain of the broiler chicks fed on diets with 1, $3 \& 5 \%$ levels during grower-finisher period.

\section{B- Feed intake and feed conversion:}

Feeding $1.25 \%$ urea diet at one-day age in second group had no effect on feed intake in the $2^{\text {nd }}$ week, while in the $1^{\text {st }} \& 3^{\text {rd }}$ weeks, it reduced feed intake by about $10 \& 11 \%$ respectively compared with control as shown in Table (8). The reducing effect become more clear in the $4^{\text {th }}$ week $(74.4 \%)$ and continued for the last three weeks of feeding, marking a total consumption about $84 \%$ of the control. On the contrary, in group 3, the urea supplementation not only had no effect on feed intake in the fourth and fifth weeks but also had an increasing effect in the sixth and seventh weeks by $3.5 \& 8.4 \%$, giving a collective rate of feeding slightly more than that of the control by about $2.1 \%$. In group 4 , feeding the urea supplemented diet in the finishing period increased intake in the sixth week of age by $12.8 \%$ and in the seventh by $11.2 \%$, making a collective increase in the seven weeks of $4.6 \%$. Kouchy $\&$ Bartosova (1973) reported that addition of $10 \mathrm{~g}$ urea $/ \mathrm{kg}$ broiler diet caused increased growth and feed consumption. On the contrary, Pervaz et al. (1994) revealed a decrease in feed intake of broilers particularly at dose levels greater than $4.0 \%$ urea.

In the second group of urea test, the reduction in growth rate was about $25 \%$, consuming less amount of food as that of the control $(84.3 \%)$, and eventually slight high feed conversion index 2.52 
compared 2.21 in control as shown in Table (9). In the third group, more food consumed and less weight gained and by turn more feed conversion (2.40). In the fourth group and in which urea feeding was limited to the finishing period, growth rate was nearly similar to the control, and more feed consumed resulting in a feed conversion index was slightly higher than the control (2.33 \& 2.21 respectively). Das et al. (1997 b) reported that feed conversion ratio was adversely affected when the diets contained more than or equal to $1 \%$ urea, while growth was not affected when they were fed up to $1.5 \%$ urea.

\section{C- Carcass dressing values \& chemical composition of broiler meat:}

The urea has no effect on the carcass dressing values as shown in Table (10) and it ranged from 70.77 to $73.87 \%$. There were significant differences $(\mathrm{P}<0.05)$ in the weights of some internal organs as a percentage of dressed carcass (Gizzard, Liver, Spleen, pro-ventriculus and heart) between different treated groups and control one. The group fed urea supplemented diet during three feeding phases recorded significantly $\mathrm{P}<0.05$ ) the highest values in the weights of gizzard, proventriculus and liver $(3.96,0.84$, and $4.70 \%$, respectively) compared to the other treated groups and control one $(3.23,0.73$, and $3.77 \%)$.

At the end of the whole experimental period ( $0-7$ weeks), there were no differences between different treated groups fed on urea and control one in the percentages of DM, CP, EE and ash of broiler meat as shown in Table (11).

\section{D- Serum biochemical parameters:}

There were no differences in the values of total serum protein and albumin between treated groups and control one at the end of the whole experimental period (0-7 weeks) as presented in Table (12). For globulin, the fourth group fed on urea supplemented diet during last feeding period (5-7 weeks) recorded value $(0.94 \mathrm{~g} / \mathrm{dL})$ nearly similar to control group $(0.80 \mathrm{~g} / \mathrm{dL})$, while second and third groups recorded the lowest values $(0.65$ and $0.61 \mathrm{~g} / \mathrm{dL})$. These results were agreed with that found by Javed et al., (2002) who reported no significant increase in serum total protein and albumin in all treated groups, while globulins were significantly or relatively higher in groups of broiler chicks fed urea. On the contrary, Das et al., (1997a) found that the serum protein content was decreased significantly at a level of $1.0 \%$ urea or more in the broiler diet.

In contrast to serum urea value, the second group (fed urea during the whole period) and third group (fed urea during growingfinishing period) recorded the highest values $(7.63$ and $8.19 \mathrm{mg} / \mathrm{dl})$ in 
comparison to fourth group $(2.60 \mathrm{mg} / \mathrm{dl})$ and control one $(1.18 \mathrm{mg} / \mathrm{dl})$. Similar results were reported by Kagan \& Ballon (1976) and Sharkawy and Mubarak (2003) who found that blood urea was increased significantly $(\mathrm{P}<0.05)$ by the addition of urea to the diet of broiler chicks.

\section{E- Economical evaluation (Monetary value):}

Total feed cost, total production cost, price of body weight net revenue and economical feed efficiency were calculated and presented in Table (13). Feeding urea for chicks during the whole experimental period reduced the economical feed efficiency which reached $70.14 \%$ of that of the control. Feeding $1.25 \%$ urea during growing-finishing period, slightly reduced economical feed efficiency by about $5 \%$ when compared with the control. The economical feed efficiency was nearly equal in the chicks fed on finisher diet containing urea $(98.42 \%)$ and control.

From the current study, it could be concluded that urea could be added to the diets of broilers at the level of $1.25 \%$ during growingfinishing and finishing periods without adversely effect on the performance.

\section{REFERENCES}

AOAC (Association of Official Analytical Chemists) (1984): Official Methods of Analysis (14 $4^{\text {th }}$ ed.) AOAC, Washington, DC.

Blair, R. and Lee, D.J.W. (1973): The effect of egg production and egg composition of adding supplements of amino acids and/or urea or dried autoclaved poultry manure to a low-protein diet. British poultry science, 14: 9-16.

Chandra, M.; Singh, S.; Gupta, P.P. and Pahuja, S. (1984): Comparative pathogenesis of nephritis in poultry induced by high protein, high calcium, urea and vit deficient diets. Acta, Veterinaria 34: 113-134.

Crampton, E.W. and Lloyd, L.E. (1959): Fundamentals of Nutrition. W.H. Freeman. San Francisco and London.

Das, K.C.; Sahu, B.K.; Dehuri, P.K. and Chand, S.K. (1997 a): Urea toxicity in chicks: histopathology. Indian Journal of Veterinary Pathology 21 (2): 113-115.

Das, K.C.; Sahu, B.K.; Dehuri, P.K. and Mahapatra, M. (1997 b): Effect of feeding urea to chicks. Indian Journal of Poultry Science 32 (2): 185-188. 
Davis, R.H. and Martindale, C.H. (1973): The performance of laying hens fed on rearing and laying diets containing urea. Br. Poult. Sci. 14: 153-160.

Guo, X.D. (1983): Preliminary observation on urea poisoning in chicken. Chinese J. Vet. Med. 9: 36-37.

Hussain, R. (1995): Effect of urea feeding on health of broiler and layer chickens. Ph. D. Thesis Dept. Vet. Path. Univ. Agri. Faisalabad, Pakistan.

Jabbar, L. (1994): Pathology of experimentally induced urea toxicity in broiler chicks, M.Sc. Thesis Dept. Vet. Path., Univ. Agri. Faisalabad, Pakistan.

Javed, M.T.; Pervaz, S.; Sabri, M.A.; Khan, H.A.; Chatta, Z.A. and Younis, M. (1995): Studies on body weight, gross pathology and some serum enzymes of urea induced toxicity in broiler chicks. Pakistan Vet. J. 15: 109-112.

Javed, M.T.; Sarwar, M.A.; Kausar, R. and Ahmed, I. (2002): Effect of feeding different levels of formalin (37\% formaldehyde) and urea on broiler health and performance. Vet. Arhiv. 72: 285302.

Kagan, A. and Ballouun, S.L. (1976): urea and aspartic acid supplementation of low-protein broiler diets. Br. Poult. Sci., 16: 403-413.

Karasawa, Y. (1986): Ammonia production and its contribution to urinary nitrogenous compounds in chickens fed low or high protein diet. Journal of Nutrition, 166: 2378-2386.

Kobayashi, S.; Koike, H. and Itoh, D.H. (1981): Effects of dietary urea on nitrogen excretion in cockerels. Japanese Poult. Sci., 18: 7885.

Koucky, M. and bartosova, J. (1973): Broiler Fattening with synthetic urea as a partial animal meal replacer. Ziuocisna uyroba, praha, 18: 367-372.

Nagalakshmi, D.; Sastry, V.R.B.; Katiyar, R.G.; Agrawai, D.K. and Verma, S.V.S. (1999): Performance of broiler chicks fed on diets containing urea ammoniated neem kernel cake. British Poultry Science, 40:77-83.

N.R.C. (1994): Nutrient requirements of poultry. $9^{\text {th }}$ ed National Academy press, Washington, D.C., USA.

Panda, S.K.; Sahu, B.K. and Rao, B.S. (1995): Urea tolerance in broiler chicken. Indian Journal of poultry science 30 (1): 46-51. 
Pervaz, S.; Javed, M.T. and Pervaiz, S. (1994): Studies on feed consumption, live body weight and clinical signs in urea induced toxicity in broiler chicks. Singapur. Vet. J. 17: 51-57.

Pervaz, S.; Javed, M.T.; Sabri, M.A. and Pervaiz, S. (1996): Hematological and biochemical findings in broilers feed different levels of urea. Pakistan. Vet. J. 16: 75-77.

SAS (1996): Statistical Analysis System. Procedures Guide: Version 6.12 Edition. SAS Institute, INC., Cary, NC, USA

Sharkawy, A.A. and Mubarak, M. (2003): Toxo-pathological effects induced by urea in broiler chicks. Toxicology letters, 144 (1): s63..

Sucio, I.; Miclea, V.; Tat, I.; Lonzone, D. (1990): Effects of replacing part of the protein in the diet with urea, in the presence of volcanic tuff zeolite, on the performance of broiler chickens. Bulitinal Institutilui Agronomic Clij Napoea 44:13-18. 